(C) The Author(s) 2016. This is an Open Access article, distributed under the terms of the Creative Commons Attribution licence (http://creativecommons. org/licenses/by/4.0/), which permits unrestricted re-use, distribution, and reproduction in any medium, provided the original work is properly cited.

\title{
Ice processes and surface ablation in a shallow thermokarst lake in the central Qinghai-Tibetan Plateau
}

\author{
Wenfeng HUANG, ${ }^{1,2}$ Runling $\mathrm{LI}^{3}{ }^{3}$ Hongwei HAN, ${ }^{3}$ Fujun NIU, ${ }^{2}$ Qingbai WU, ${ }^{2}$ \\ Wenke WANG ${ }^{1}$ \\ ${ }^{1}$ Key Laboratory of Subsurface Hydrology and Ecological Effects in Arid Region, Chang'an University, Ministry of Education, \\ Chang'an, China \\ ${ }^{2}$ State Key Laboratory of Frozen Soil Engineering, Cold and Arid Regions Environmental and Engineering Research Institute, \\ Chinese Academy of Sciences, Lanzhou, China \\ ${ }^{3}$ State Key Laboratory of Coastal and Offshore Engineering, Dalian University of Technology, Dalian, China \\ Correspondence: Wenfeng Huang <huangwenfeng@chd.edu.cn>
}

\begin{abstract}
The Qinghai-Tibetan Plateau (QTP) is characterized by a cold climate and a large number of lakes. The long ice season necessitates study of the widespread ice covers in the region. An unprecedented multidisciplinary field campaign was conducted on lake ice processes in the central QTP during the period 2019-13. The study lake generally froze up in late October or early November, and broke up in mid or late April, with a maximum ice thickness of $50-70 \mathrm{~cm}$. The mass balances at both ice surface and bottom were measured continuously. Significant ice surface sublimation/ablation was detected and accounted for up to $40 \%$ of the whole ice thickness over the ice season. A simple heattransfer model was developed for the surface ice loss. The calculated values were in good agreement with the observations. They also indicated that atmospheric conditions, including low air humidity and prevailing strong winds, are the primary drivers of the ice surface sublimation.
\end{abstract}

KEYWORDS: ice physics, lake ice, surface melt

\section{INTRODUCTION}

The Qinghai-Tibetan Plateau (QTP) is characterized by high mean elevation (4000-5000 ma.s.l.) and a cold climate, with a mean annual air temperature of -3 to $-7^{\circ} \mathrm{C}$, and is thus often called the Third Pole of the Earth. The QTP covers an area of $\sim 2.7 \times 10^{6} \mathrm{~km}^{2}, 55.6 \%$ of which is classified as continuous and discontinuous permafrost. Recently, a significant degradation of permafrost has been reported, which is probably due to the warming climate and increased human activity (Wang and others, 2000; Cheng and Wu, 2007). There are widespread reports of thermokarst lake expansion from, for instance, sub-Arctic lowlands and Siberian and alpine regions (Kokelj and Jorgenson, 2013; Niu and others, 2014).

Thermokarst lakes occupy closed depressions formed by ground subsidence following the thawing of ice-rich permafrost or melting of massive ice. In recent decades thermokarst lakes have attracted much attention as they usually cause soil erosion, transform permafrost landscapes (Arp and others, 2011; Morgenstern and others, 2013), change regional groundwater discharge, causing local ecosystem variations (Yoshikawa and Hinzman, 2003; Pohl and others, 2009), and release carbon preserved in the frozen soils in the form of $\mathrm{CO}_{2}$ and $\mathrm{CH}_{4}$, thereby providing positive feedback to global warming (Walter and others, 2006; Shakhova and others, 2010). Most of this work has been conducted in Arctic and sub-Arctic regions. In China, sparse and limited observations have been conducted on the thermokarst lakes in the QTP with respect to their impacts on infrastructures and permafrost regimes, development mechanisms (Wang and others, 1979; Lin and others, 2010, 2012; Niu and others, 2011), methane emission (Jin and others, 1999; Wu and others, 2014) and the physics of seasonally ice-covered lakes. The responses of ice covers and ice-covered lakes in the QTP to warming climate and anthropogenic influences have not been studied extensively by field campaigns or modelling methods.

The QTP is one of the regions in China possessing the most abundant lakes and ponds. There are 32843 lakes (area $>0.001 \mathrm{~km}^{2}$ ), with a total area of $\sim 43000 \mathrm{~km}^{2}$, accounting for $1.4 \%$ of the total area of the QTP (Ma and others, 2011; Zhang and others, 2014). Approximately 96\% of all lakes are small, with an area $<1 \mathrm{~km}^{2}$, while the large lakes $\left(>1 \mathrm{~km}^{2}\right)$ make up $96 \%$ of the total lake area (Zhang and others, 2014). In recent decades, although some lakes have shrunk or disappeared, the total number and area of lakes have been increasing due to new lake formation and extension of individual lake shorelines (Zhang and others, 2011, 2014; Lei and others, 2013). Lakes are known to affect regional climate, exchanging energy and moisture with the atmosphere. Owing to the rarity of disturbance from human activities, QTP lake variation is a good indicator of climate change (Lei and others, 2013; Liao and others, 2013; Li and others, 2014). Specifically, lake ice phenology has been widely regarded as an alternative indicator of local and regional climatic variability and abnormality (Liston and Hall, 1995a; Magnuson and others, 2000; Zhang and Jeffries, 2000; Lei and others, 2012). The lake ice cover significantly influences the heat and momentum exchange between the air and the underlying water body, since it introduces a different surface for light and heat properties (Huang and others, 2013a,b) and kinetic roughness compared with open water. Lake ice changes the under-ice light field, which plays a pivotal role in the aquatic ecosystem (e.g. by controlling the rate of photosynthesis) and thereby the heat and mass transfer in the lake-sediment system (Golosov and others, 2007; Kirillin and others, 2012). Furthermore, the wintertime effluxes of gases such as 


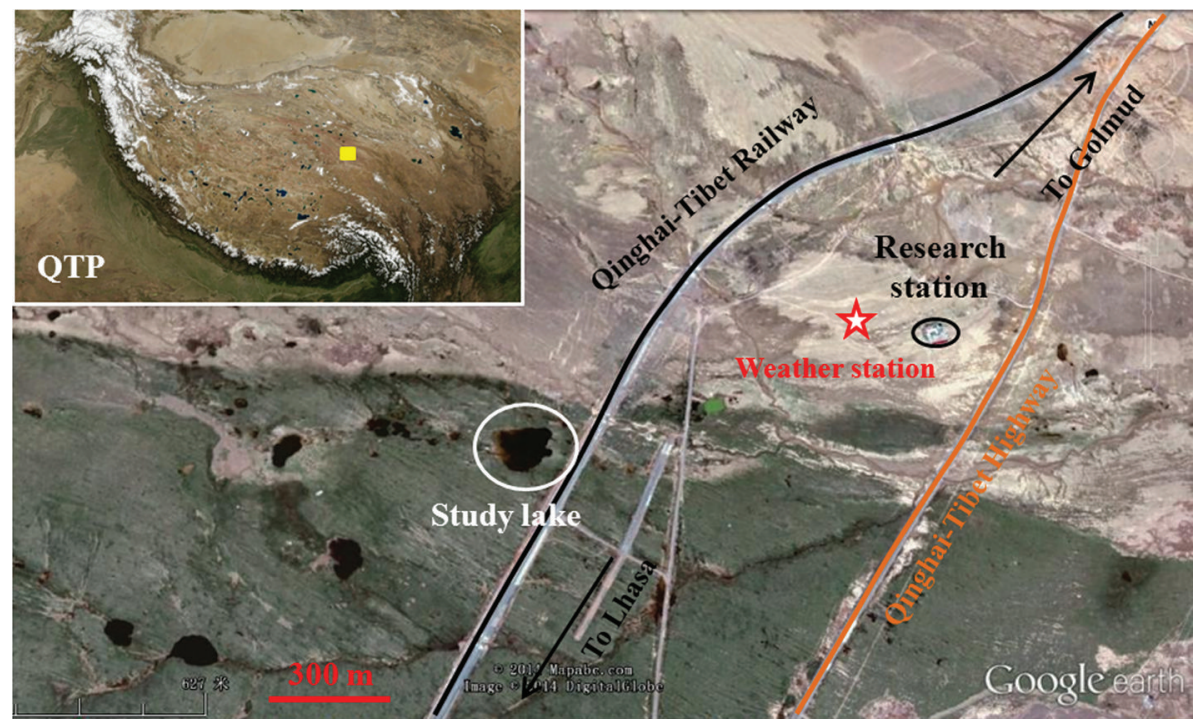

Fig. 1. Location of thermokarst lake BLH-A. Inset illustrates the entire QTP outline, with the yellow square denoting the study site. A meteorological station (red star) is located $\sim 800 \mathrm{~m}$ from lake BLH-A.

methane and carbon dioxide from lake sediments can be entrapped within and beneath the lake ice cover, ceasing their release to the atmosphere temporarily or seasonally and thus altering the local greenhouse gas balance (Walter and others, 2010; Wu and others, 2014). A lake ice cover also provides a convenient and solid platform for wintertime on-ice transport, operation and investigation (Winslow and others, 2014). These issues necessitate the accurate representation of QTP lake ice processes, especially with respect to ice thickness evolution.

Of the limited research conducted on QTP lakes, most has been undertaken using moderate-resolution satellite imagery to quantify lake ice phenology (Chen and others, 1995; Che and others, 2009; Qu and others, 2012; Kropáček and others, 2013). However, very few in situ field data exist to calibrate these results.

During the winters of 2010-13, we conducted in situ investigations of ice phenology in a typical shallow thermokarst lake (unofficially named lake BLH-A) of the central QTP with respect to ice physical structure, thermal conductivity, ice thickness and temperature as well as atmospheric conditions. Here we present the results, develop a heat-transfer model for the ice surface mass budget based on atmospheric boundary layer theory, and discuss the effects of ice processes on the heat budget of permafrost and water balance of QTP lakes.

\section{FIELD INSTRUMENTATION}

Lake BLH-A is situated in the Beiluhe basin in the central QTP at $4600 \mathrm{ma.s.l}$. This small basin is underlain by continuous permafrost $50-80 \mathrm{~m}$ thick with a high percentage of ground ice. The mean annual air temperature is -3.8 to $-5.0^{\circ} \mathrm{C}$ and the mean annual ground temperature -0.5 to $-2.0^{\circ} \mathrm{C}$. Approximately $21 \mathrm{~km}$ of the Qinghai-Tibet Railway (QTR) passes through the basin. There are 16 thermokarst lakes along both sides of this section of the QTR, with a total area of $1.4 \times 10^{5} \mathrm{~m}^{2}$ (Fig. 1). Water depths are typically about $0.5-2.5 \mathrm{~m}$. Lake BLH-A is located $\sim 100 \mathrm{~m}$ west of the QTR at $34^{\circ} 49.5^{\prime} \mathrm{N}, 92^{\circ} 55.4^{\prime} \mathrm{E}$. The lake is perennially closed, has a surface area of $15000 \mathrm{~m}^{2}$ and is elliptical, with major and minor axes of about 150 and $120 \mathrm{~m}$, respectively. It is $2.5 \mathrm{~m}$ deep, with a stable stage through the year. It is fresh, with a concentration of total dissolved solids of $1.30 \mathrm{~g} \mathrm{~L}^{-1}$. Abundant submerged plants grow in the lake throughout the year (Lin and others, 2010).

Field campaigns were conducted in lake BLH-A over three winters from 2010 to 2013. Most equipment was deployed before fall freeze-up (Fig. 2). The thermistor cable and underice up-looking sonar were mounted on a floater moored to the bank by four ropes. The thermistor cable recorded the water and ice column temperature at an interval of $5 \mathrm{~cm}$. The up-looking sonar was used to monitor freezing and melting of the bottom surface of the ice cover. Two thermistor cables were placed in boreholes Nos 1 and 2, both of $10 \mathrm{~m}$ depth, to measure the temperature of lake sediments every $0.5 \mathrm{~m}$. On 9 December 2010 a down-looking ultrasonic range finder (URF) was fixed onto a steel pipe that had previously been inserted into borehole 2 . The steel pipe was strictly stationary all the time, so the URF measured the vertical displacement of the air-ice interface. In winter 2012/13, only one thermistor cable was deployed to monitor the ice and water temperature. The equipment was powered by several solar panels and sampled every $30 \mathrm{~min}$. The weather station, located $800 \mathrm{~m}$ from the lake, monitored air temperature, air pressure, water vapor pressure, wind and incident solar irradiance at 2 and $10 \mathrm{~m}$ above the ground surface. The instrumentation is summarized in Table 1.

The instrumentation deployed for monitoring lake ice processes provided us with the freezing and melting of the water-ice interface $\left(H_{\mathrm{b}}\right)$ and the displacement of the air-ice interface $\left(H_{\mathrm{s}}\right)$, which actually represented the surface ice sublimation (i.e. $\left.H_{\mathrm{s}}\right)$ and the ice thickness $\left(H_{\mathrm{i}}=H_{\mathrm{b}}-H_{\mathrm{s}}\right)$. The thermistor cables provided the temperature of the air and the ice-water-sediment column. Meteorological data spanning the 2010/11 ice season (Fig. 3) were obtained from Beiluhe research station (BRS) (Fig. 1). These data consisted of the air temperature $\left(T_{\mathrm{a}}\right)$, wind speed $\left(V_{\mathrm{a}}\right)$, relative humidity $(\mathrm{RH})$ and atmospheric pressure $\left(P_{\mathrm{a}}\right)$. Unfortunately, we failed to gain access to the meteorological data of the two other winters (Table 1). However, the air temperature profiles documented over three winters gave some insight 

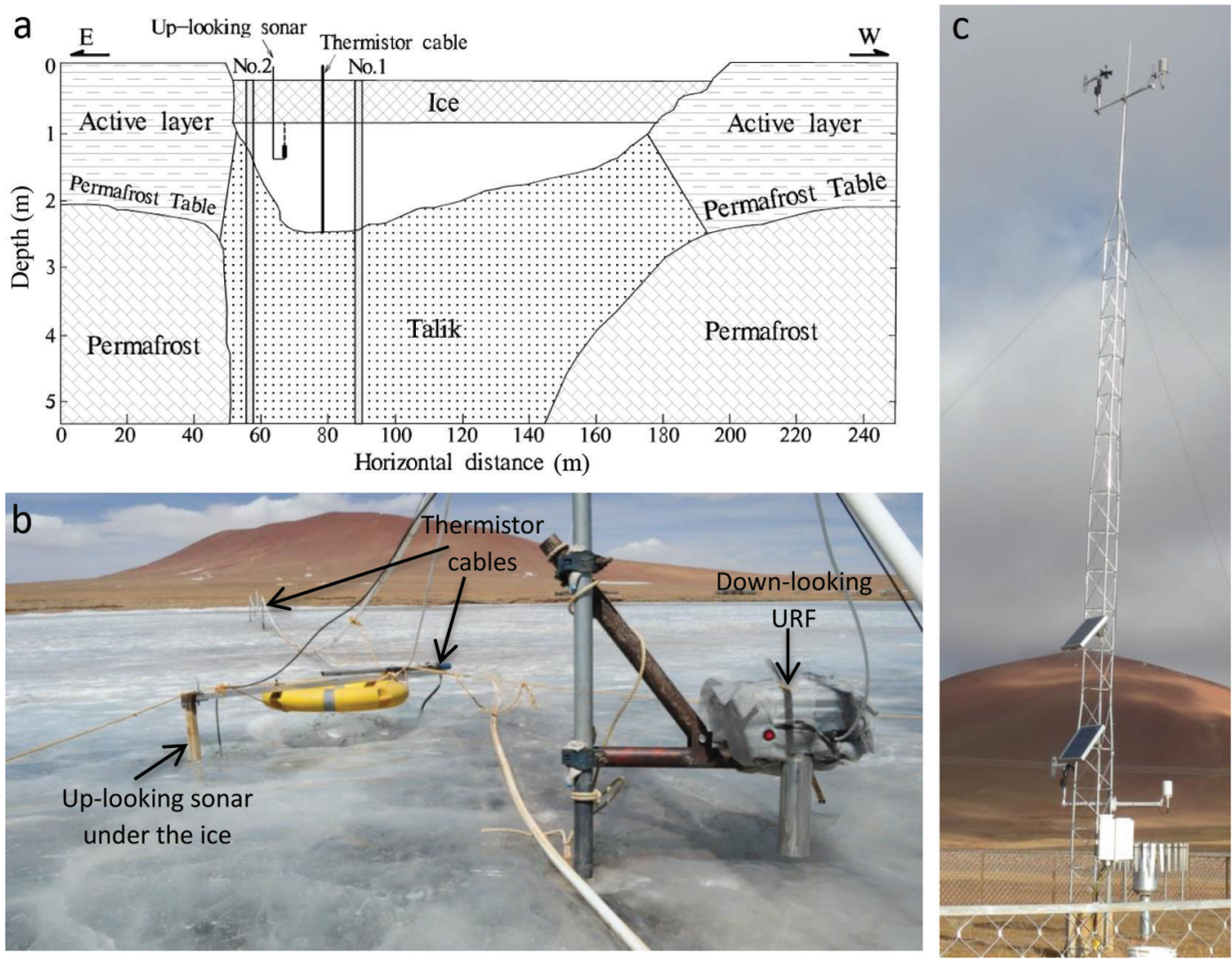

Fig. 2. (a) Schematic (Huang and others, 2012) and (b) configuration of field instrumentation in lake BLH-A; (c) meteorological station. Borehole Nos 1 and 2 were drilled in the lake to monitor the temperature variation of lake sediment (talik or permafrost). The up-looking sonar and down-looking URF were deployed to detect the variation of the ice-water and ice-air interface, respectively. The thermistor cable measured the water temperature profiles. The stratigraphy beneath and around the lake was determined using ground-penetrating radar and borehole records (Lin and others, 2010).

into the atmospheric conditions, especially for accounting for the ice phenology.

\section{RESULTS}

\section{Meteorological conditions}

Generally, the growth and decay of lake ice are dictated by local meteorological and hydrological variables, especially solar radiation, air temperature and water temperature at the ice-water interface. The 2010/11 winter was a normal winter in this basin. From late October to the end of March the mean daily air temperature was persistently below freezing point, with several days in January below $-20^{\circ} \mathrm{C}$, and thereafter climbed progressively to above $0^{\circ} \mathrm{C}$. The QTP is characterized by strong solar irradiance and yearround strong wind. The daily peaks of solar radiation were 650-1000 $\mathrm{W} \mathrm{m}^{-2}$, with an approximate daily mean atmospheric longwave radiation of $200 \mathrm{~W} \mathrm{~m}^{-2}$. Over the studied ice season the prevailing northwest winds usually

Table 1. Information on all instruments deployed in the lake ice campaign and the meteorological station

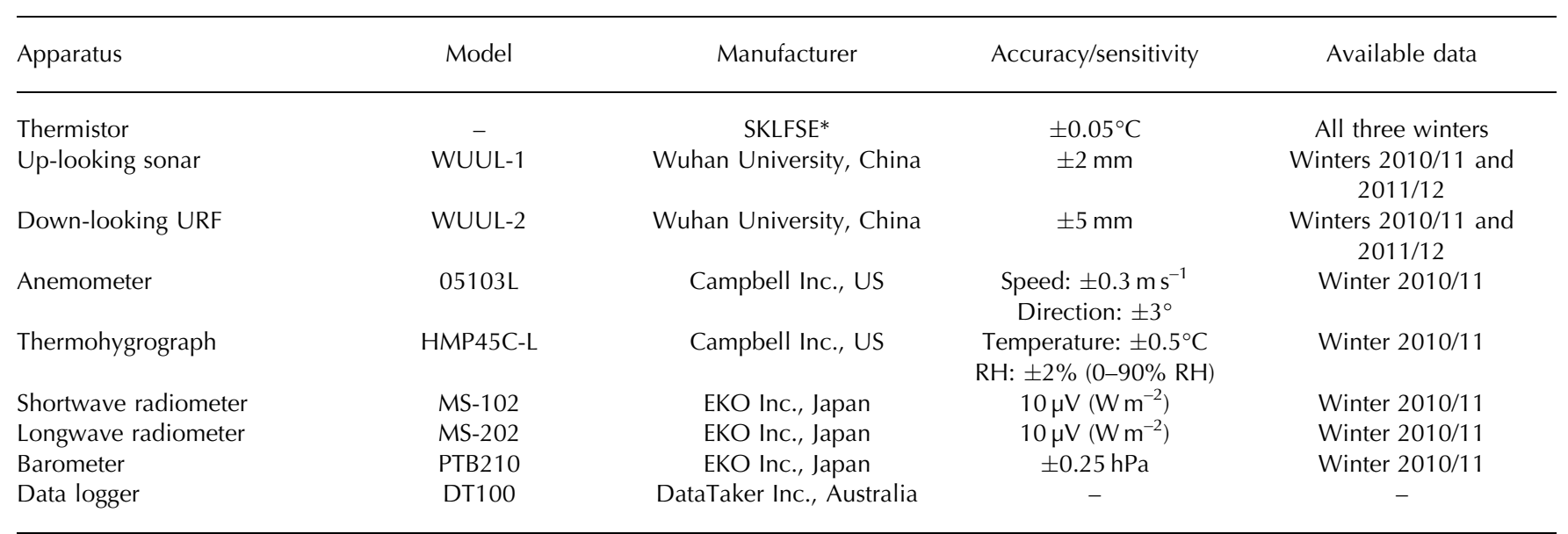

*SKLFSE: State Key Laboratory of Frozen Soil Engineering, Chinese Academy of Sciences. 

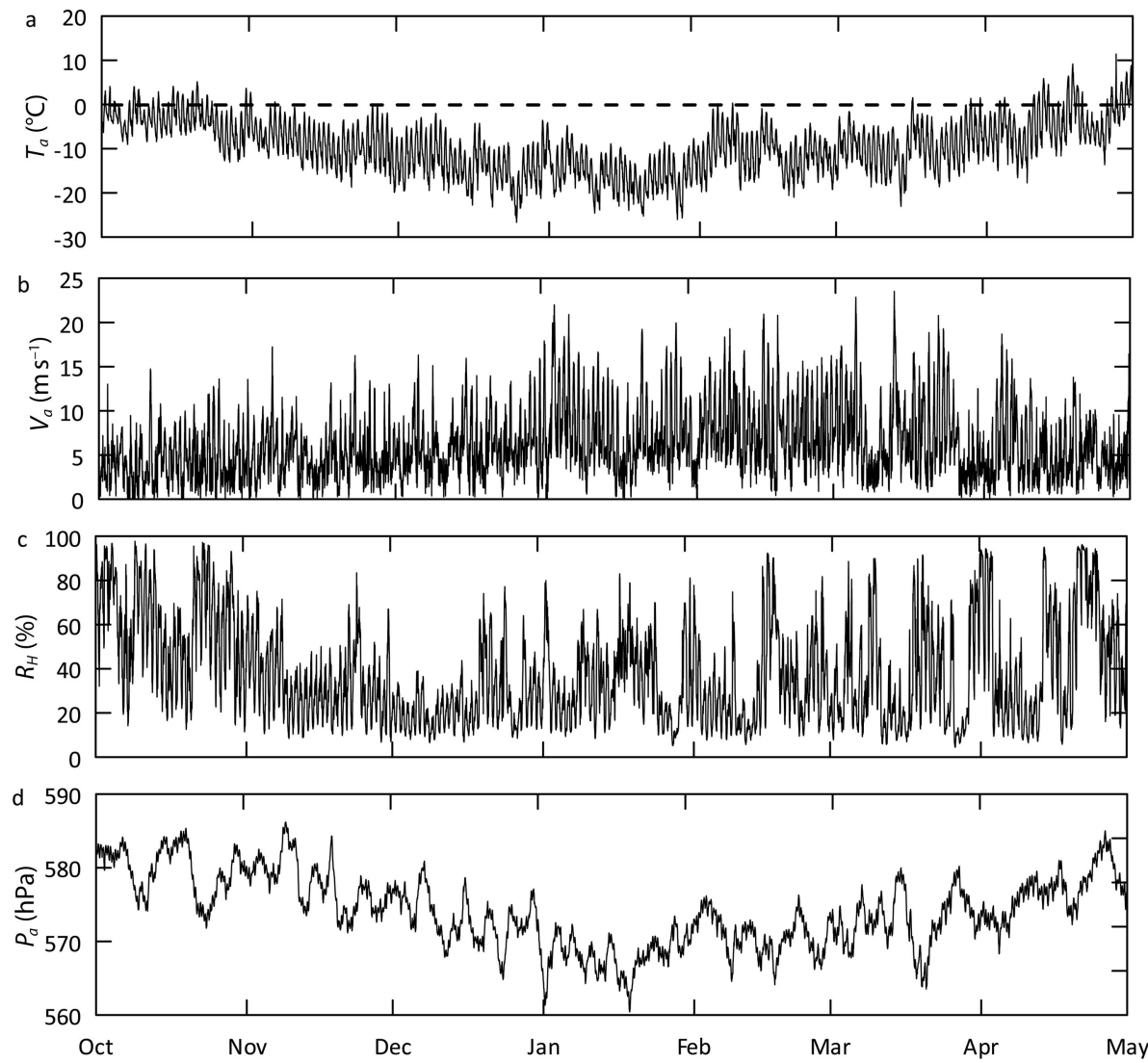

Fig. 3. Time series of (a) air temperature, (b) wind speed, (c) relative humidity and (d) atmospheric pressure.

commenced at noon and ended at midnight, with mean daily speed $>5 \mathrm{~m} \mathrm{~s}^{-1}$. The air on QTP is dry, especially in winter. Over a large portion of the winter, the relative air humidity was $<40 \%$. No precipitation events occurred during the winter, causing a bare-ice surface exposed to the air. Occasionally, a dust film (fine sand and clay transported by winds) covered the lake ice surface for a few days, which probably reduced surface albedo and accelerated surface ablation.

Air temperature is an integrated meteorological indicator, which is controlled synchronously by solar irradiation, air turbulence and weather events. Table 2 summarizes the air temperature over three winters. Winter 2012/13 was normal, as was that of 2010/11, whereas winter 2011/12 was severe and had the lowest mean and minimum daily air temperatures and the most degree-days below freezing. However, all three winters were characterized by minor snowfall, low air humidity and strong wind.

Table 2. Statistics on air temperature over three winters. Mean and minimum air temperature from October to April. FDD represents the degree-days below freezing from the freeze-up date to the maximum thickness date

\begin{tabular}{lccc}
\hline Winter & $\begin{array}{c}\text { Mean } \\
{ }^{\circ} \mathrm{C}\end{array}$ & $\begin{array}{c}\text { Minimum } \\
{ }^{\circ} \mathrm{C}\end{array}$ & $\begin{array}{c}\text { FDD } \\
{ }^{\circ} \mathrm{Cd}\end{array}$ \\
\hline $2010 / 11$ & -9.47 & -18.59 & -1459.46 \\
$2011 / 12$ & -9.61 & -22.75 & -1807.40 \\
$2012 / 13$ & -9.42 & -19.72 & -1126.33
\end{tabular}

\section{Ice process}

Based on the experiences of technicians working in the BRS and our observations over three winters, with the decreasing air temperature in fall, typically a thin ice cover is observed to form and melt intermittently in late October. In early November, a stable ice sheet covers the entire lake (freezeup). Lake ice usually reaches the annual maximum thickness of $\sim 40-70 \mathrm{~cm}$ in late March. Finally, the ice melts and disintegrates (break-up) in late April and disappears (ice-off) in early May. Throughout the ice season, little snow accumulates on the ice surface, largely due to lack of snowfall and prevailing strong winds.

In the winters of 2010-13, a stable ice cover formed $\sim 4$ 7 days after ice was first observed. The ice phenology of lake BLH-A is listed in Table 3. In winter 2012/13 the ice cover formed nearly 1 month later than in winter 2011/12, and the difference in maximum thickness was up to $20 \mathrm{~cm}$. Lake ice phenology is a combined result of air turbulence, weather events, solar irradiation, and especially the air temperature

Table 3. Ice phenology of lake BLH-A during the winters of 201013

\begin{tabular}{lcccc}
\hline Winter & $\begin{array}{c}\text { Freeze-up } \\
\text { (date) }\end{array}$ & $\begin{array}{c}\text { Break-up } \\
\text { (date) }\end{array}$ & Ice duration & $\begin{array}{c}\text { Maximum thickness } \\
\text { (date) } \\
\text { days }\end{array}$ \\
\hline $2010 / 11$ & $9 \mathrm{Nov}$ & $15 \mathrm{Apr}$ & 158 & $59(4 \mathrm{Mar})$ \\
$2011 / 12$ & $24 \mathrm{Oct}$ & $25 \mathrm{Apr}$ & 183 & $65(12 \mathrm{Mar})$ \\
$2012 / 13$ & $21 \mathrm{Nov}$ & $16 \mathrm{Apr}$ & 147 & $47(20 \mathrm{Feb})$
\end{tabular}



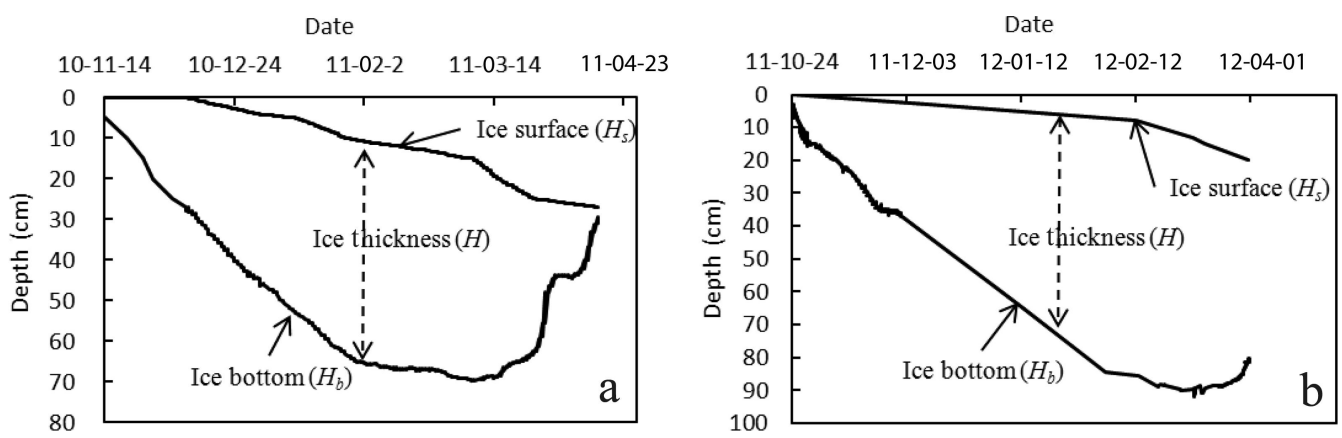

Fig. 4. Bottom and surface elevations (in $\mathrm{cm}$ ice not water equivalent) relative to the original ice surface of the lake ice cover at the bottom and surface during winter (a) 2010/11 and (b) 2011/12. The graphs start at an ice thickness of $5 \mathrm{~cm}$ in order to skip the unstable period of thin ice cover. The surface sublimation and bottom melting data were missed during the melt period of winter 2011/12 (i.e. after $31 \mathrm{March}$ ) due to instrument failure. Date format is yy-mm-dd.

during the fall cooling and freezing, winter growth and spring warming (Liston and Hall, 1995a; Lei and others, 2012). In order to analyze the annual variation of lake ice processes, simple statistics on the air temperature and freezing degree-days are presented from October through April for the three winters (Table 2). Winter 2011/12 was clearly much colder than the others and had the coldest October and April, leading to the longest ice duration. The greatest number of degree-days below freezing accounted for the thickest ice cover in winter 2011/12.

We also noted that during all winters investigated, large gas bubbles were incorporated within the upper part of the ice column (to $\sim 30 \mathrm{~cm}$ below the original surface). These bubble clusters affected the light transmittance and attenuation, and the thermal conductivity of the bulk ice, which are key factors in lake ice modelling (Huang and others, 2012, 2013b).

Ice thickness evolution, especially the maximum thickness, is the most important indicator in characterizing the ice processes. The time series of lake ice thickness was determined from simultaneous readings of the under-ice sonar and above-ice URF (Fig. 4) for winters 2010/11 and $2011 / 12$. As the stable lake ice cover formed, the ice cover in lake BLH-A grew linearly from the bottom with elapsed freezing time until it reached maximum thickness in early February. The bottom growth rate was estimated at $\sim 0.7-$ $0.8 \mathrm{~cm} \mathrm{~d}^{-1}$. From early February to mid-March, the growth from below was slow or even ceased. After mid-March, bottom melting occurred quickly. Over the entire ice season, ice surface ablation was detected and seemed to start from the appearance of lake ice cover. During the period of fast bottom congelation (from freeze-up to early February), the total surface ablation was $\sim 7-11 \mathrm{~cm}$, with an

Table 4. Lake ice growth and ablation (negative values) rates

\begin{tabular}{|c|c|c|c|}
\hline Winter & $\begin{array}{l}\text { Fast congelation } \\
\text { (before early Feb) } \\
\qquad \mathrm{cm} \text { ice } \mathrm{d}^{-1}\end{array}$ & $\begin{array}{l}\text { Equilibrium period } \\
\text { (early Feb to mid-Mar) } \\
\text { cm ice } \mathrm{d}^{-1}\end{array}$ & $\begin{array}{c}\text { Melting period } \\
\text { (after mid-Mar) } \\
\text { cm ice } \mathrm{d}^{-1}\end{array}$ \\
\hline 2010/11 & $\begin{array}{c}\text { Surface: }-0.13 \\
\text { Bottom: } 0.70\end{array}$ & $\begin{array}{c}\text { Surface: }-0.21 \\
\text { Bottom: } 0.11\end{array}$ & $\begin{array}{l}\text { Surface: }-0.23 \\
\text { Bottom: }-1.36\end{array}$ \\
\hline $2011 / 12$ & $\begin{array}{c}\text { Surface: }-0.08 \\
\text { Bottom: } 0.78\end{array}$ & $\begin{array}{c}\text { Surface: }-0.25 \\
\text { Bottom: } 0.08\end{array}$ & $\begin{array}{l}\text { No data } \\
\text { No data }\end{array}$ \\
\hline
\end{tabular}

estimated ablation rate of $0.11 \mathrm{~cm} \mathrm{~d}^{-1}$. During the equilibrium period of bottom growth (early February to midMarch), the surface ablation rate was $0.20-0.25 \mathrm{~cm} \mathrm{~d}^{-1}$. Over the melting period, the total surface ablation was $\sim 7 \mathrm{~cm}$, with a loss rate of $\sim 0.23 \mathrm{~cm} \mathrm{~d}^{-1}$ (Table 4). According to the observations from the three winters, the total surface ablation removed $\sim 25-40 \%$ of the maximum thickness resulting from the bottom congelation.

\section{Surface mass balance over the ice season}

Water surface evaporation is a key component of the lake water balance. The lake evaporation/sublimation in cold low-altitude regions is usually minor and used to be neglected during the ice-covered period. However, in the QTP, an ice-covered lake was observed to lose water at a significant rate by surface ice sublimation (Fig. 4) as well as melt at the surface during the spring. Here we developed an energy-budget based model for ice surface sublimation on the basis of atmospheric boundary-layer theory.

At the ice surface, the turbulent latent heat flux $Q_{l e}$ from ice to air was assumed generally to equal the heat used to sublimate the ice, i.e.

$$
Q_{\text {le }}=\rho_{\mathrm{a}} L_{\mathrm{E}} C_{\mathrm{E}}\left(q_{\mathrm{a}}-q_{\mathrm{s}}\right) V_{\mathrm{a}}=\rho_{\mathrm{i}} L_{\mathrm{E}} \frac{\mathrm{d} E}{\mathrm{~d} t}
$$

Thus

$$
\frac{\mathrm{d} E}{\mathrm{~d} t}=\frac{\rho_{\mathrm{a}} C_{\mathrm{E}}\left(q_{\mathrm{a}}-q_{\mathrm{s}}\right) V_{\mathrm{a}}}{\rho_{\mathrm{i}}}
$$

where $\left(q_{\mathrm{a}}-q_{\mathrm{s}}\right)$ denotes the difference in specific humidity between air and ice surface, $\rho_{\mathrm{a}}$ and $\rho_{\mathrm{i}}$ are the density of air and lake ice, respectively, $L_{E}$ is the latent heat of sublimation, $C_{\mathrm{E}}$ is the bulk transfer coefficient, $V_{\mathrm{a}}$ is the wind speed and $\mathrm{d} E / \mathrm{d} t$ denotes the rate of direct sublimation of ice at the surface.

The air density in the QTP is a function of air temperature and pressure. Ignoring the effect of water vapor pressure, the air density was parameterized with an empirical function:

$$
\rho_{\mathrm{a}}=\rho^{\star} \frac{P_{\mathrm{a}}}{P^{\star}} \frac{T^{\star}}{T_{\mathrm{aK}}}
$$

where $\rho^{\star}$ is the air density at standard temperature $T^{\star}$ and pressure $P^{\star}$ (Table 5), and $P_{\mathrm{a}}$ and $T_{\mathrm{ak}}$ are the measured air pressure and temperature (in K), respectively. The ice surface was presumed to be at its saturated vapor pressure $e_{\mathrm{s}}$, which was determined as a function of surface temperature $T_{\mathrm{sK}}$ (in 


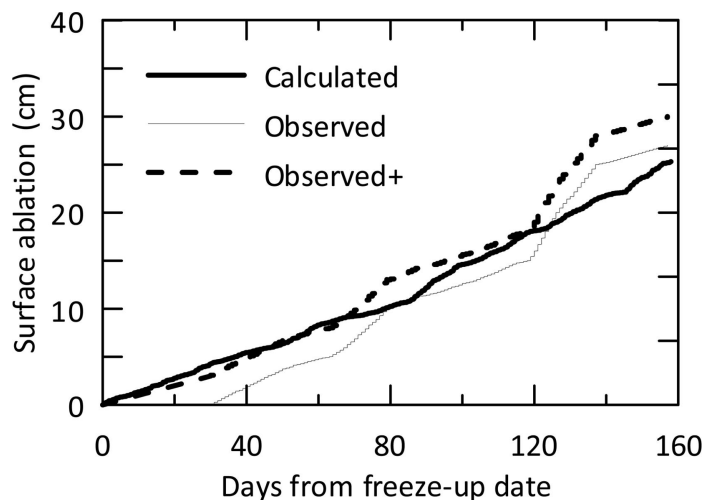

Fig. 5. Calculated ice (thick solid line) surface sublimation (in $\mathrm{cm}$ ice) at a time interval of $30 \mathrm{~min}$; the horizontal axis denotes the time from freeze-up date (i.e. 9 November 2010). Because the ice surface ablation was observed (thin solid line) from 9 December 2010, we assumed a total ablation of $3 \mathrm{~cm}$ had taken place before that date and replotted the observed data (dashed line).

K) using the Goff-Gratch formula (WMO, 1988):

$$
\begin{aligned}
\operatorname{lge}_{\mathrm{s}}= & 9.096936\left(1-T^{\star} / T_{\mathrm{sK}}\right)-3.56654 \lg \left(T^{\star} / T_{\mathrm{sK}}\right) \\
& +0.87682\left(1-T_{\mathrm{sK}} / T^{\star}\right)+0.78614
\end{aligned}
$$

However, the ice surface temperature is controlled by complex processes (Launiainen and Cheng, 1998; Yang and others, 2012). For simplicity, we use the air temperature instead of ice surface temperature in Eqn (4), neglecting the minor effect of the small difference in temperature between air and ice surfaces on the saturation vapor pressure, especially during the ice growth period. This is reasonable in that the saturation vapor pressure is not significantly sensitive to minor changes in air surface temperature. The specific humidity was determined by

$$
\begin{gathered}
q_{\mathrm{s}}=\frac{0.622 \mathrm{e}_{\mathrm{s}}}{p_{\mathrm{a}}} \\
q_{\mathrm{a}}=\mathrm{RH} \cdot q_{\mathrm{s}}
\end{gathered}
$$

where $p_{\mathrm{a}}$ and $\mathrm{RH}$ denote the measured air pressure and relative humidity, respectively.

Accurate determination of the bulk transfer coefficient $C_{\mathrm{E}}$ is complicated (Andreas, 1987; Launiainen, 1995; Liston and Hall, 1995b). A large number of previous in situ and modelling efforts indicate that the value of $C_{E}$ falls in the range $1.0-2.0 \times 10^{-3}$ for ice and snow surfaces (Andreas, 1987; Launiainen, 1995; Valeo and others, 2005; Dundas and Byrne, 2010). All parameters above are summarized in Table 5 .

The modelling results of ice evaporation over the whole ice season as well as the observed data are plotted in Figure 5. Considering the surface sublimation observations started on 9 December (about 1 month after freeze-up), it is reasonable to assume that the surface ice had sublimated $\sim 3 \mathrm{~cm}$ of ice if the ice surface began sublimating from freeze-up. In this way, we obtained the whole time series of surface ablation from freeze-up to break-up (dashed line in Fig. 5) through interpolation extension. The model developed in this paper was in good agreement with the observations, with a root-mean-square error (RMSE) of $2.5 \mathrm{~cm}$. Nevertheless, the observed data became progressively larger than the calculated data after day 120, and remained $\sim 5 \mathrm{~cm}$ larger after day 140 , i.e. during the spring melting period. This is likely because the surface ablation
Table 5. List of constants

\begin{tabular}{lcc}
\hline Parameter & Description & Value \\
\hline$\rho_{\mathrm{i}}$ & Ice density & $905 \mathrm{~kg} \mathrm{~m}^{-3}($ Huang and \\
& & others, 2012) \\
$L_{\mathrm{E}}$ & Latent heat of ice sublimation & $2.83 \times 10^{6} \mathrm{~J} \mathrm{~kg}^{-1}$ \\
$\rho^{*}$ & Air density at $T^{*}$ and $P^{*}$ & $1.293 \mathrm{~kg} \mathrm{~m}^{-3}$ \\
$P^{*}$ & Standard atmospheric pressure & $101325 \mathrm{~Pa}$ \\
$T^{*}$ & Freezing temperature & $273.15 \mathrm{~K}$ \\
$C_{\mathrm{E}}$ & Bulk transfer coefficient & $1.5 \times 10^{-3}$ (Andreas, 1987; \\
& & \\
\hline
\end{tabular}

during melting was dictated jointly by the ice sublimation and melting at the surface. The latter has been reported previously in many regions (Jakkila and others, 2009; Kirillin and others, 2012; Yang and others, 2012).

In order to quantify the sensitivity of the surface ice sublimation from the model to coefficients and to meteorological forcing, and to identity the key drivers of ice sublimation on the QTP, a series of sensitivity tests was conducted with respect to the bulk coefficient $C_{\mathrm{E}}$, wind speed $U_{a}$, relative humidity $\mathrm{RH}$, air temperature $T_{\mathrm{a}}$ and air pressure $P_{\mathrm{a}}$. The test results are shown in Figure 6. Just as Eqn (1) indicates, the model is sensitive to changes in the bulk transfer coefficient, i.e. the atmospheric boundary-layer conditions have significant impact on lake ice sublimation. Analysis indicated that the value $\left(1.5-2.0 \times 10^{-3}\right)$ was acceptable for $C_{E}$ in this region throughout the ice season. The modelling results were also sensitive to changes in wind speed, relative humidity and ice surface temperature (i.e. approximately air temperature in Fig. 6d), but not to air pressure (not shown). The former three factors can be regarded as the potential drivers of ice sublimation over the QTP.

In the northeastern plains of China (mean elevation 50$60 \mathrm{~m}$ ), the air temperature and freezing degree-days over the ice season are equivalent to those over the central QTP. The ice freezing rate at the ice-water interface is generally $0.5-$ $2.0 \mathrm{~cm} \mathrm{~d}^{-1}$, which is close to that of lake BLH-A. Winds are not strong (mean monthly wind speed $<3 \mathrm{~m} \mathrm{~s}^{-1}$ ) and the relative humidity is generally $>60 \%$ in the winter. The total sublimation is $<5 \mathrm{~cm}$ over the entire ice season, which is much lower than that of lake BLH-A. In the light of the sensitivity of ice sublimation to wind speed and relative humidity, we can conclude that the key drivers of ice sublimation over the central QTP are the above two factors. Furthermore, climate warming over the QTP due to global warming and growing anthropogenic influences has been demonstrated (Liu and Chen, 2000). The air temperature increase is expected to cause an increase in surface ice sublimation due to its high sensitivity to surface temperature (Fig. 6d; Table 6).

The regional climate and meteorology around the studied lake are similar to those in the McMurdo Dry Valleys, Antarctica, where strong westerly winds and low air humidity prevail through the year (Dugan and others, 2013). The perennial lake ice cover has a winter average surface sublimation rate of $0.03-0.06 \mathrm{~cm}_{\text {ice }} \mathrm{d}^{-1}$, which is much lower than our results for seasonal lake ice cover in the QTP (Table 4). The significant differences in solar radiation, air and surface temperature are likely to bring about the above differences in sublimation rate. 

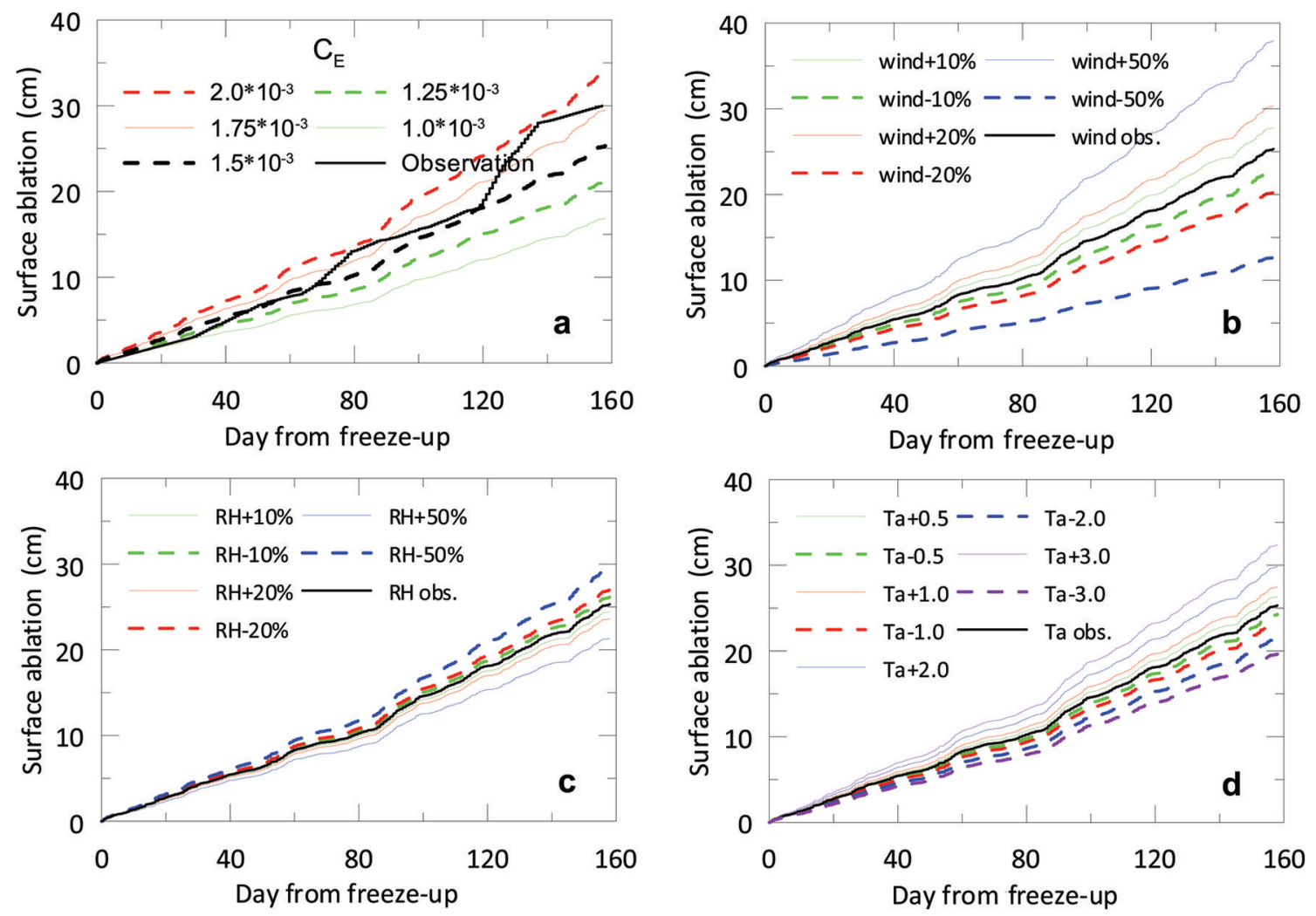

Fig. 6. Sensitivity of surface ice ablation (in $\mathrm{cm}$ ice) to (a) the bulk transfer coefficient $C_{\mathrm{E}}$ (b) wind speed $V_{\mathrm{a}}$ (c) relative humidity RH and (d) air temperature $T_{\mathrm{a}}\left({ }^{\circ} \mathrm{C}\right)$.

\section{DISCUSSION}

Although there are a large number of small shallow thermokarst lakes across the QTP, there have been few studies of their geomorphological dynamics, thermal and dynamical processes, aquatic environments, and impact on permafrost degradation and hydrological processes. Investigation and modelling of the seasonal ice processes in these lakes are urgently required to clarify these subjects.

Owing to the spatial deviation in lake depth, size and even salinity (freshwater to brackish), a lake may or may not freeze through its whole depth, causing either a grounded or floating lake ice cover. A floating ice cover allows a portion of liquid water to sustain an essential habitat for aquatic biota through the winter. However, the ice cover cuts off oxygen replenishment from the air, and reduces the solar radiation into the underlying water, depressing the rate of photosynthesis of submerged macrophytes and primary producers and leading to oxygen depletion (Golosov and others, 2007; Kirillin and others, 2012). Furthermore, the underlying water body can release heat into the lake sediments and banks, causing a talik in the permafrost layers (Lin and others, 2010, 2012). A grounded ice cover may seasonally restrict the lake's use as a habitat and water supply, and depress the rate of permafrost retreat compared with a floating ice cover (Zhang and Jefferies, 2000; Arp and others, 2011, 2012). Ice modelling may provide a means of determining the threshold between grounded and floating ice regimes.

Winter ice surface ablation (sublimation and evaporation) may play a pivotal part in the water budget in lakes, ponds and rivers over the QTP. In lake BLH-A, the surface ice sublimated about $27 \mathrm{~cm}$ w.e. across the lake surface through the entire ice season from November 2010 to April 2011. This may be the dominant path for wintertime lake water loss since groundwater seepage from the lake may largely decrease due to the ambient ground freezing in continuous permafrost regions. In this study, we introduced a simple model to simulate the ice surface sublimation. It indicated that the prevailing strong wind and the low air humidity were the key processes driving the strong surface sublimation. These processes would be expected to be key reasons why ice thicknesses in QTP lakes are significantly smaller

Table 6. Structure of the sensitivity tests of the model to each atmospheric forcing

\begin{tabular}{|c|c|c|c|c|c|c|c|c|c|c|}
\hline \multirow[b]{2}{*}{ Range } & \multicolumn{3}{|c|}{ Wind speed } & \multicolumn{3}{|c|}{ Relative humidity $^{+}$} & \multicolumn{4}{|c|}{ Ice skin temperature } \\
\hline & $+10 \%$ & $+20 \%$ & $+50 \%$ & $+10 \%$ & $+20 \%$ & $+50 \%$ & $+0.5^{\circ} \mathrm{C}$ & $+1.0^{\circ} \mathrm{C}$ & $+2.0^{\circ} \mathrm{C}$ & $+3.0^{\circ} \mathrm{C}$ \\
\hline & $-10 \%$ & $-20 \%$ & $-50 \%$ & $-10 \%$ & $-20 \%$ & $-50 \%$ & $-0.5^{\circ} \mathrm{C}$ & $-1.0^{\circ} \mathrm{C}$ & $-2.0^{\circ} \mathrm{C}$ & $-3.0^{\circ} \mathrm{C}$ \\
\hline \multirow[t]{2}{*}{$\Delta H_{\mathrm{s}} / H_{\mathrm{s}}^{*}$} & $+10 \%$ & $+20 \%$ & $+50 \%$ & $-3.3 \%$ & $-6.5 \%$ & $-15.7 \%$ & $+4.3 \%$ & $8.7 \%$ & $18.0 \%$ & $28.1 \%$ \\
\hline & $-10 \%$ & $-20 \%$ & $+50 \%$ & $+3.3 \%$ & $+6.6 \%$ & $+16.6 \%$ & $-4.1 \%$ & $-8.0 \%$ & $15.5 \%$ & $-22.4 \%$ \\
\hline
\end{tabular}

*Calculated over the entire ice season.

${ }^{+}$Let $\mathrm{RH}=100 \%$ if $\mathrm{RH}>100$. 
than those in cold plains of low altitudes under an equivalent number of freezing degree-days. For instance, in northeastern China, lake/reservoir ice covers grow up to 100-120 cm (Li and others, 2010, 2011). The ice surface sublimation detected and the model presented in this paper may also have some implications for the surface mass balance of glaciers on the QTP during winter.

\section{CONCLUDING REMARKS}

Ice processes were investigated in a typical shallow lake in the central QTP over three winters in 2010-13. The lake froze up in late October or early November and broke up in mid- or late April, with a maximum thickness of $50-70 \mathrm{~cm}$. To our knowledge, this is the first time that lake ice processes in this region have been observed. Significant ice surface ablation was detected throughout the winter. We developed a simple model by using the heat-balance method for simulating ice sublimation. The predicted ablation at the surface was in good agreement with observations. It indicated that the unique weather characteristics of the QTP (e.g. low humidity and strong wind) led to strong ice sublimation.

In future work, a skin temperature instrument will be deployed, which can validate the heat-balance methods for retrieving surface temperature (Launiainen and Cheng, 1998). These field data will also help to validate and assess current lake ice models for shallow lakes, such as the highresolution thermodynamic snow and sea-ice (HIGHTSI) model and the computationally efficient FLake model (Launiainen and Cheng, 1998; Mironov and others, 2010; Yang and others, 2012), and an accurate ice model will be developed based on the parameterizations of various heat fluxes, especially the solar radiation transfer, water-lakesediment heat exchange and the heat flux from water to ice.

\section{ACKNOWLEDGEMENTS}

This research was supported by the National Natural Science Foundation of China (41402203, 41376186, 41230314) and the Open Fund of the State Key Laboratory of Frozen Soil Engineering (SKLFSE201202). We appreciate the excellent technical assistance and logistic support from all staff working at the Beiluhe research station. Matti Leppäranta from Helsinki University and Bin Cheng from the Finnish Meteorological Institute are gratefully acknowledged for constructive discussions. We also thank all anonymous reviewers for constructive suggestions on improving the quality of this paper.

\section{REFERENCES}

Andreas EL (1987) A theory for the scalar roughness and the scalar transfer coefficient over snow and sea ice. Bound.-Layer Meteorol., 38, 159-184

Arp CD, Jones BM, Urban FE and Grosse G (2011) Hydrogeomorphological processes of thermokarst lakes with grounded-ice and floating-ice regimes on the Arctic coastal plain, Alaska. Hydrol. Process., 25, 2422-2438 (doi: 10.1002/hyp.8019)

Arp CD, Jones BM, Lu Z and Whitman MS (2012) Shifting balance of thermokarst lake ice regimes across the Arctic coastal plain of northern Alaska. Geophys. Res. Lett., 39(16), L16503 (doi: 10.1029/2012GL052518)

Che T, Li X and Jin R (2009) Monitoring the frozen duration of Qinghai Lake using satellite passive microwave remote sensing low frequency data. Chinese Sci. Bull., 54(6), 787-791 (doi: 10.1007/s11434-009-0044-3)

Chen X, Wang G, Li W, Zeng Q, Jin D and Wang L (1995) Lake ice and its remote sensing monitoring in the Tibetan Plateau. J. Glaciol. Geocryol., 17(3), 241-246 [in Chinese]

Cheng G and Wu T (2007) Responses of permafrost to climate change and their environmental significance, Qinghai-Tibet Plateau. J. Geophys. Res., 112(F2), F02S03 (doi: 10.1029/ 2006JF000631)

Dugan HA, Obryk MK and Doran PT (2013) Lake ice ablation rates from permanently ice-covered Antarctic lakes. J. Glaciol., 59(215), 491-498 (doi: 10.3189/2013JoG12J080)

Dundas CM and Byrne S (2010) Modelling sublimation of ice exposed by new impacts in the martian mid-latitudes. Icarus, 206, 716-728 (doi: 10.1016/j.icarus.2009.09.007)

Golosov S, Maher OA, Schipunova E, Terzhevik A, Zdorovennova G and Kirilin G (2007) Physical background of the development of oxygen depletion in ice-covered lakes. Oecologia, 151, 331-340 (doi: 10.1007/s0442-006-0543-8)

Huang W, Li Z, Han H, Niu F, Lin Z and Lepparänta M (2012) Structural analysis of thermokarst lake ice in Beiluhe Basin, Qinghai-Tibet Plateau. Cold Reg. Sci. Technol., 72, 33-42 (doi: 10.1016.j.coldregions.2011.11.005)

Huang W, Li Z, Liu X, Zhao H, Guo S and Jia Q (2013a) Effective thermal conductivity of reservoir freshwater ice with attention to high temperature. Ann. Glaciol., 54(62), 189-195 (doi: 10.3189/ 2013AoG62A075)

Huang W, Han H, Shi L, Nui F, Deng Y and Li Z (2013b) Effective thermal conductivity of thermokarst lake ice in Beiluhe Basin, Qinghai-Tibet Plateau. Cold Reg. Sci. Technol., 85, 34-41 (doi: 10.1016/j/coldregions.2012.08.001)

Jakkila J, Leppäranta M, Kawamura T, Shirasawa K and Salonen K (2009) Radiation transfer and heat budget during the ice season in Pääjärvi, Finland. Aquat. Ecol., 43, 681-692 (doi: 10.1007/ s10452-009-9275-2)

Jin H, Wu J, Cheng G, Nakano T and Sun G (1999) Methane emissions from wetlands on the Qinghai-Tibet Plateau. Chinese Sci. Bull., 44(24), 2282-2286

Kirillin G and 11 others (2012) Physics of seasonally ice-covered lakes: a review. Aquat. Sci., 74, 659-682 (doi: 10.1007/s00027012-0279-y)

Kokelj SV and Jorgenson MT (2013) Advances in thermokarst research. Permafrost Periglac. Process., 24, 108-119 (doi: 10.1002/ppp.1779)

Kropáček J, Masussion F, Chen F, Hoerz S and Hochschild V (2013) Analysis of ice phenology of lakes on the Tibetan Plateau from MODIS data. Cryosphere, 7, 287-301 (doi: 10.5194/tc-7287-2013)

Launiainen J (1995) Derivation of the relationship between the Obukhov stability parameter and the bulk Richardson number for flux-profile studies. Bound--Layer Meteorol., 76, 165-179

Launiainen J and Cheng B (1998) Modelling of ice thermodynamics in natural water bodies. Cold Reg. Sci Technol., 27, 153-178

Lei R, Leppäranta M, Cheng B, Heil P and Li Z (2012) Changes in ice-season characteristics of a European Arctic lake from 1964 to 2008. Climatic Change, 115, 725-739 (doi: 10.1007/s10584012-0489-2)

Lei YB, Ya TD, Bird BW, Yang K, Zhai JQ and Sheng YW (2013) Coherent lake growth on the central Tibetan Plateau since the 1970s: characterization and attribution. J. Hydrol., 483, 61-67 (doi: 10.1016/j.hydrol.2013.01.003)

Li S, Jiang Y and Luo R (2014) Responses of lake environment to climatic changes on the Tibetan Plateau, western China. Acta Geol. Sin., 88(1), 17

Li Z, Jia Q, Zhang B, Leppäranta M, Lu P and Huang W (2010) Influences of gas bubble and ice density on ice thickness measurement by GPR. Appl. Geophys., 7(2), 105-113 (doi: 10.1007/s11770-010-0234-4)

Li Z, Huang W, Jia Q and Leppäranta M (2011) Distributions of crystals and gas bubbles in reservoir ice during growth period. 
Water Sci. Eng., 4(2), 204-211 (doi: 10.3882/j.issn.1674.2011. 02.008)

Liao J, Shen G and Li Y (2013) Lake variation in response to climate change in the Tibetan Plateau in the past 40 years. Int. J. Digit. Earth, 6(6), 534-549 (doi: 10.1080/17538947.2012.656290)

Lin Z, Niu F, Xu Z, Xu J and Wang P (2010) Thermal regime of a thermokarst lake and its influence on permafrost, Beiluhe Basin, Qinghai-Tibet Plateau. Permafrost Periglac. Process., 21, 315-324 (doi: 10.1002/ppp.692)

Lin Z, Niu F, Liu H, Lu J and Luo J (2012) Numerical simulation of lateral thermal process of a thaw lake and its influence on permafrost engineering on Qinghai-Tibet Plateau. Chinese J. Geotech. Eng., 34(8), 1394-1402 [in Chinese]

Liston GE and Hall DK (1995a) Sensitivity of lake freeze-up and break-up to climate change: a physically based modelling study. Ann. Glaciol., 21, 387-393

Liston GE and Hall DK (1995b) An energy-balance model of lakeice evolution. J. Glaciol., 41(138), 373-382

Liu X and Chen B (2000) Climatic warming in the Tibetan Plateau during recent decades. Int. J. Climatol., 20, 1729-1742

Ma R and 10 others (2011) China's lakes at present: number, area and spatial distribution. Sci. China Earth Sci., 41(3), 394-401 (doi: 10.1007/s11430-0101-4052-6)

Magnuson JJ and 13 others (2000) Historical trends in lake and river ice cover in the Northern Hemisphere. Science, 289(5485), 1743-1746

Mironov D, Heise E, Kourzeneva E, Ritter B, Schneider N and Terzhevik A (2010) Implementation of the lake parameterisation scheme FLake into the numerical weather prediction model COSMO. Boreal Environ. Res., 15, 218-230

Morgenstern A and 8 others (2013) Evolution of thermokarst in East Siberian ice-rich permafrost: a case study. Geomorphology, 201, 363-379 (doi: 10.1016.j.geomorph.2013.07.011)

Niu F, Lin Z, Liu H and Lu J (2011) Characteristics of thermokarst lakes and their influence on permafrost in Qinghai-Tibet Plateau. Geomorphology, 132(3), 222-233 (doi: 10.1016/ j.geomorph.2011.05.011)

Niu FJ, Cheng GD, Luo J, and Lin ZJ (2014) Advances in thermokarst lake research in permafrost regions. Sci. Cold Arid Reg., 6(4), 388-397 (doi: 10.3724/SP.J.1226.2014.00388)

Pohl S, Marsh P, Onclin C and Russell M (2009) The summer hydrology of a small upland tundra thaw lake: implications to lake drainage. Hydrol. Process., 23, 2536-2546 (doi: 10.1002/ hyp.7283)

Qu B, Kang S, Chen F, Zhang Y and Zhang G (2012) Lake ice and its effect factors in the Nam Co Basin, Tibetan Plateau. Progressus Inquisitiones Mutatione Climatis, 8(5), 327-333 [in Chinese] (doi: 10.3969/j/issn.1673-1719.2012.05.003)
Shakhova N, Semiletov I, Salyuk A, Yusupov V, Kosmach D and Gustafsson O (2010) Extensive methane venting to the atmosphere from sediments of the east Siberian Arctic shelf. Science, 327(5970), 1246-1250 (doi: 10.1126/science.1182221)

Valeo C, Skone SH, Ho CLI, Poon SKM and Shrestha SM (2005) Estimating snow evaporation with GPS-derived precipitable water vapor. J. Hydrol., 307, 196-203 (doi: 10.1016/ j.jhydrol.2004.10.009)

Walter KM, Zimov SA, Chanton JP, Verbyla D and Chapin FS III (2006) Methane bubbling from Siberian thaw lakes as a positive feedback to climate warming. Nature, 443(7107), 71-75 (doi: 10.1038/nature05040)

Walter KM, Vas DA, Brosius L, Chapin FS, Zimov SA and Zhuang Q (2010) Estimating methane emissions from northern lakes using ice-bubble surveys. Limnol. Oceanogr., 8, 592-609 (doi: 10.4319/lom.2010.8.592)

Wang JC, Wang SL and Qiu GQ (1979) Permafrost along the Qinghai-Xizang highway. Acta Geogr. Sin., 34(1), 18-32

Wang S, Jin H, Li S and Zhao L (2000) Permafrost degradation on the Qinghai-Tibet Plateau and its environmental impacts. Permafrost Periglac. Process., 11, 43-53

Winslow LA and 6 others (2014) Autonomous year-round sampling and sensing to explore the physical and biological habitability of permanently ice-covered Antarctic lakes. Mar. Technol. Soc. J., 48(5), 8-17

World Meteorological Organization (WMO) (1988) General meteorological standards and recommended practices. WMO Technical Regulations (WMO-No. 49), Appendix A

Wu Q, Zhang P, Jiang G, Yang Y, Deng Y and Wang X (2014) Bubble emissions from thermokarst lakes in the Qinghai-Xizang Plateau. Quat. Int., 321, 65-70 (doi: 10.1016/j.quaint.2013.11.028)

Yang Y, Leppäranta M, Cheng B and Li Z (2012) Numerical modelling of snow and ice thickness in Lake Vanajavesi, Finland. Tellus, 64A, 17202 (doi: 10.3402/tellus.v64i0.17202)

Yoshikawa K and Hinzman LD (2003) Shrinking thermokarst ponds and groundwater dynamics in discontinuous permafrost near Council, Alaska. Permafrost Periglac. Process., 14, 151-160 (doi: 10.1002/ppp.451)

Zhang G, Xie H, Kang S, Yi D and Ackley SF (2011) Monitoring lake level changes on the Tibetan Plateau using ICESat altimetry data (2003-2009). Remote Sens. Environ., 115, 1733-1742 (doi: 10.1016/j.rse.2011.03.005)

Zhang G, Yao T, Xie H, Zhang K and Zhu F (2014) Lake's state and abundance across the Tibetan Plateau. Chinese Sci. Bull., 59(24), 3010-3021 (doi: 10.1007/s11434-014-0258-x)

Zhang TJ and Jeffries MO (2000) Modelling inter-decadal variation of lake-ice thickness and sensitivity to climatic change in northernmost Alaska. Ann. Glaciol., 31, 339-347 